\title{
Assessment of Two Macromethods and Three Micromethods of Culturing Human White Blood Cells for Chromosome Analysis
}

\author{
N. P. BISHUN, W. R. M. MORTON, and P. FROGGATT
}

From the Departments of Anatomy and of Social and Preventive Medicine, Queen's University, Belfast, Northern Ireland

Three variations of the micromethod, previously described (Robinson, Bishun, Rashad, and Morton, 1964) for the culture of human white blood cells (WBCs) from capillary blood of newborn infants, have been used on peripheral venous blood of adults. The reliability of the micromethods has been assessed by comparing the mitotic indices for these methods with those obtained for two macromethods of culturing WBCs from venous blood as described below. The mitotic index is calculated for each method as the percentage of dividing cells seen in a total of 1,000 , or more, cells. The present results do not include work done on the capillary blood of adults, the results of which will be reported later.

\section{Materials and Methods}

Macromethods. In each case, $20 \mathrm{ml}$. peripheral venous blood, usually obtained from the antecubital veins, were withdrawn into a dry-heat sterilized syringe. ro ml. of this blood were immediately discharged directly from the syringe, after removal of the needle, into each of two heparinized bottles (Evans Medical), the caps replaced after flaming, and the bottles gently shaken. The treatment of the bloods differed from this point onwards. One bottle was allowed to remain at room temperature and the blood was used for one macromethod and for the three micromethods. The second bottle was immediately placed in a flask containing ice and left to cool for half an hour. This was used for the second macromethod. All cultures were incubated without replacement of the air by another gas.

Macromethod $A$. Peripheral venous blood at room temperature was allowed to stand for one to one and a half hours. The supernatant plasma, usually about $\mathrm{I}-\mathrm{I} \cdot \mathrm{5}$ ml., was drawn off and put under sterile conditions into a culture bottle. $3 \mathrm{ml}$. of T.C. medium 199 (Glaxo) together with three drops of Phytohemagglutinin $P$ (Difco) were added and the whole incubated for 70 hours.

Received March 31, 1965.
Macromethod B. Eight drops of Phytohemagglutinin $M$ (Difco) were added to the cooled venous blood after half an hour, and the bottle was shaken and replaced in the cooled flask for another five minutes. The blood was then centrifuged at 600 r.p.m. for seven minutes. The supernatant plasma was withdrawn, an equal amount of T.C. medium 199 was added, and the mixture was incubated for 70 hours.

Micromethods. In each case two drops of heparinized venous whole blood kept at room temperature and three drops of Phytohemagglutinin $\mathbf{M}$ (Difco) were added to the culture medium immediately after returning to the laboratory, and incubated for 70 hours. The three culture media were made up as follows:

Micromethod C. $4 \mathrm{ml}$. T.C. medium 199, and I ml. human AB serum.

Micromethod D. $3 \mathrm{ml}$. T.C. medium 199, and I $\mathrm{ml}$. human AB serum. I ml. chick embryo extract (C.E.E.) prepared from ro-day incubated hen eggs.

Micromethod E. 5 ml. T.C. medium 199 alone.

After Treatment. 'Colcemid' (0.1 ml. of a $0.001 \%$ solution per $\mathrm{ml}$. of total fluid volume) was added to each culture after 70 hours of incubation, and incubation was continued for a further two and a half hours. Harvesting was carried out as previously described (Bishun, Morton, and McLaverty, 1964).

\section{Results}

Since the chromosome morphology and spreads were fairly uniform from all cultures, the mitotic indices may be used as a fairly reliable means of assessing the comparative growth rates in the various cultures. Table I shows the mitotic indices for each method for 24 patients ( 44 females ( $46 / \mathrm{XX}$ ), 2 mosaic females ( $46 / \mathrm{XX}, 45 / \mathrm{XO}$ ), 7 males ( $46 / \mathrm{XY}$ ), and one Klinefelter male (47/XXY)), ranging in age from 2 to 72 years.

The percentages of successful mitotic indices obtained by the five methods ( $A$ to $E$ ) on blood from 24 subjects in Table I were transformed to their square-root, and compared by (a) analysis of 
TABLE I

COMPARISON OF MITOTIC INDICES FOR FIVE METHODS OF CULTURING HUMAN WHITE BLOOD CELLS

\begin{tabular}{|c|c|c|c|c|c|c|c|}
\hline \multirow{3}{*}{ Culture No. } & \multirow{3}{*}{ Patient's Age } & \multirow{3}{*}{ Chromosome Constitution } & \multicolumn{5}{|c|}{$\begin{array}{l}\text { Mitotic Indices } \\
\text { (No. of dividing cells } \\
\text { per roo cells) }\end{array}$} \\
\hline & & & \multicolumn{2}{|c|}{ Macromethods } & \multicolumn{3}{|c|}{ Micromethods } \\
\hline & & & $\mathbf{A}$ & B & C & $\mathbf{D}$ & $\mathbf{E}$ \\
\hline $\begin{array}{l}N / 91 / 64 \\
N / 92 / 64 \\
N / 93 / 64 \\
N / 96 / 64 \\
N / 98 / 64\end{array}$ & $\begin{array}{l}72 \\
18 \\
24 \\
71 \\
17\end{array}$ & $\begin{array}{c}46 / \mathrm{XY} \\
46 / \mathrm{XX} \\
46 / \mathrm{XX} \\
47 / \mathrm{XXY} \\
46 / \mathrm{XX}\{\text { mosaic } \\
45 / \mathrm{XO}\}\end{array}$ & $\begin{array}{r}2 \\
5 \\
5 \\
3 \\
10\end{array}$ & $\begin{array}{r}10 \\
1 \\
10 \\
15 \\
20\end{array}$ & $\begin{array}{l}5 \\
2 \\
5 \\
3 \\
5\end{array}$ & $\begin{array}{r}7 \\
1 \\
10 \\
5 \\
6\end{array}$ & $\begin{array}{r}8 \\
2 \\
5 \\
4 \\
10\end{array}$ \\
\hline $\begin{array}{l}N / 99 / 64 \\
N / 100 / 64 \\
N / 102 / 64 \\
N / 104 / 64 \\
N / 105 / 64\end{array}$ & $\begin{array}{l}13 \\
18 \\
20 \\
18 \\
28\end{array}$ & $\left.\begin{array}{c}46 / X X \\
46 / X X \\
46 / X Y \\
46 / X Y \\
46 / X X\} \text { mosiac } \\
45 / X O\end{array}\right\}$ m & $\begin{array}{r}10 \\
3 \\
20 \\
10 \\
10\end{array}$ & $\begin{array}{r}20 \\
5 \\
5 \\
15 \\
15\end{array}$ & $\begin{array}{r}2 \\
10 \\
5 \\
10 \\
3\end{array}$ & $\begin{array}{r}3 \\
5 \\
10 \\
3 \\
2\end{array}$ & $\begin{array}{l}2 \\
6 \\
5 \\
5 \\
3\end{array}$ \\
\hline $\begin{array}{l}N / 108 / 64 \\
N / 112 / 64 \\
N / 116 / 64 \\
N / 121 / 64 \\
N / 126 / 64 \\
N / 127 / 64 \\
N / 128 / 64 \\
N / 129 / 64 \\
N / 130 / 64 \\
N / 131 / 64 \\
N / 133 / 64 \\
N / 134 / 64 \\
N / 135 / 64 \\
N / 136 / 64 \\
\end{array}$ & $\begin{array}{r}47 \\
28 \\
29 \\
45 \\
4 \\
2 \\
34 \\
24 \\
22 \\
45 \\
21 \\
19 \\
17 \\
34 \\
\end{array}$ & $\begin{array}{l}46 / \mathrm{XX} \\
46 / \mathrm{XX} \\
46 / \mathrm{XX} \\
46 / \mathrm{XY} \\
46 / \mathrm{XYY} \\
46 / \mathrm{XY} \\
46 / \mathrm{XX} \\
46 / \mathrm{XX} \\
46 / \mathrm{XX} \\
46 / \mathrm{XX} \\
46 / \mathrm{XY} \\
46 / \mathrm{XX} \\
46 / \mathrm{XX} \\
46 / \mathrm{XX} \\
\end{array}$ & $\begin{array}{r}10 \\
3 \\
15 \\
10 \\
15 \\
10 \\
2 \\
3 \\
3 \\
5 \\
12 \\
5 \\
10 \\
8\end{array}$ & $\begin{array}{r}15 \\
4 \\
25 \\
10 \\
20 \\
10 \\
17 \\
8 \\
15 \\
10 \\
15 \\
14 \\
10 \\
15\end{array}$ & $\begin{array}{r}10 \\
28 \\
8 \\
15 \\
10 \\
8 \\
15 \\
3 \\
10 \\
8 \\
10 \\
8 \\
10 \\
10 \\
\end{array}$ & $\begin{array}{r}4 \\
4 \\
5 \\
5 \\
3 \\
2 \\
10 \\
2 \\
5 \\
3 \\
10 \\
7 \\
5 \\
8\end{array}$ & $\begin{array}{l}5 \\
5 \\
2 \\
3 \\
3 \\
2 \\
1 \\
3 \\
1 \\
2 \\
3 \\
3 \\
2 \\
3 \\
2\end{array}$ \\
\hline Total & & & 189 & 304 & 203 & 125 & 85 \\
\hline Average mitotic indices & & & $7 \cdot 9$ & $12 \cdot 7$ & $8 \cdot 5$ & $5 \cdot 2$ & \\
\hline
\end{tabular}

TABLE II

ANALYSIS OF VARIANCE ON THE TRANSFORMED (SOUARE-ROOT) VARIATE

\begin{tabular}{|c|c|c|c|c|c|}
\hline Source of Variation & Sums of Squares & D.F. & Mean Square & Variance Ratio & Probability \\
\hline Between methods & $36 \cdot 7823$ & 4 & $9 \cdot 1956$ & $16 \cdot 5003$ & $p<0.001$ \\
\hline Between subjects & 19.0226 & 23 & & $I \cdot 484 I$ & $0.10>p>0.05$ \\
\hline Residual & $51 \cdot 2723$ & 92 & 0.5573 & & \\
\hline Total & $107 \cdot 0772$ & 119 & & & \\
\hline
\end{tabular}

TABLE III

STUDENT'S $t$ TEST BETWEEN MEANS OF TRANSFORMED VARIATES FOR EACH METHOD

\begin{tabular}{c|c|c|c|c}
\hline Methods & $\begin{array}{c}\text { Difference } \\
\text { Between } \\
\text { Means }\end{array}$ & $\begin{array}{c}\text { Standard } \\
\text { Error of } \\
\text { Difference }\end{array}$ & $t$ & Probability \\
\hline A-B & -0.7675 & 0.2561 & 2.9969 & $0.02>\mathrm{p}>0.01$ \\
-C & -0.0996 & 0.2520 & 0.3952 & $0.70>\mathrm{p}>0.60$ \\
-D & 0.4750 & 0.2163 & 2.1960 & $0.05>\mathrm{p}>0.02$ \\
-E & 0.8679 & 0.2064 & 4.2049 & $\mathbf{p}<0.001$ \\
B-C & 0.6679 & 0.2598 & 2.5708 & $0.02>\mathrm{p}>0.01$ \\
-D & 1.2425 & 0.2254 & 5.5124 & $\mathbf{p}<0.001$ \\
-E & 1.6354 & 0.2159 & 7.5748 & $\mathbf{p}<0.001$ \\
C-D & 0.5746 & 0.2207 & $\mathbf{2 . 6 0 3 5}$ & $0.02>\mathrm{p}>0.01$ \\
-E & 0.9675 & 0.2110 & 4.5853 & $\mathbf{p}<0.001$ \\
D-E & 0.3929 & 0.1667 & 2.3569 & $0.05>\mathrm{p}>0.02$ \\
\hline
\end{tabular}

Note: Degrees of freedom $=46$ throughout. 
variance (Table II), and (b) Student's $t$ test between all possible pairs of means (Table III). Table II shows that there is a significant difference between methods $(p<0.00 I)$ but not between subjects $(0$. IO $>p>0.05)$. Table III shows that method $B$ was the most successful, method $E$ the least successful, methods $\mathrm{A}$ and $\mathrm{C}$ equally successful, and both in turn better than $\mathrm{D}$.

\section{Conclusions}

The best results are obtained where the total amount of blood is large and is cooled immediately after withdrawal from the subject. When only small amounts of blood are readily available, microculture method C, in which T.C. medium 199 and
$\mathrm{AB}$ serum are used, gives as good results as macromethod A, in which the blood is not cooled before culture.

We should like to record our thanks to Mrs. E. E. Kingston who helped with the computations, and to the Queen's University, Belfast, and the Northern Ireland Hospitals Authority for grants which enabled this work to be carried out.

\section{REFERENCES}

Bishun, N. P., Morton, W. R. M., and McLaverty, B. (1964). Macromethod for culturing leucocytes for chromosomal analysis. Lancet, 2, 3 I 5 .

Robinson, J. S., Bishun, N. P., Rashad, M. N., and Morton, W. R. M. (1964). Chromosome analysis from capillary blood. ibid., 1,328 . 